\title{
Exogenous Production of Cold-Active Cellulase From Psychrophilic Actinobacteria With Increased Cellulose Hydrolysis Efficiency
}

\section{Sivasankar Palaniappan}

Periyar University

Poongodi Subramaniam

Annamalai University

Sivakumar Kannan

Annamalai University

Wahidah H Al-Qahtani

King Saud University

Arokiyaraj Selvaraj

Sejong University

Jothiramalingam Rajabathar ( $\nabla$ rjothiram@gmail.com )

King Saud University https://orcid.org/0000-0002-0120-1483

\section{Research Article}

Keywords: Cold-active enzyme, Cellulase, Psychrophiles, Cellulose hydrolysis, Actinobacteria, Southern Ocean.

Posted Date: September 27th, 2021

DOl: https://doi.org/10.21203/rs.3.rs-844138/v1

License: (c) (1) This work is licensed under a Creative Commons Attribution 4.0 International License. Read Full License 


\section{Abstract}

Actinobacteria form the largest phylum consisting of diverse, ecologically unique and biologically active members. The actinobacteria are omnipresent and occur in various habitats such as cold environment, aquatic, desert and terrestrial ecosystems. Though the studies are available on actinobacteria at various habitats very few reports are available on cold tolerant/loving actinobacteria in the Southern Ocean part of the Antarctic Ocean. In this context, the present work was designed to isolate and characterize the actinobacteria in the Polar Front region of the Southern Ocean waters and species of Nocardiopsis and Streptomyces were identified. Among those, the psychrophilic actinobacterium, Nocardiopsis dassonvillei PSY13 was found to have good cellulolytic activity and it was further studied for the production and characterization of cold-active cellulase enzyme. The latter was found to have a specific activity of 6.36 $\mathrm{U} / \mathrm{mg}$ and a molar mass of $48 \mathrm{kDa}$ with a 22.9 -fold purification and $5 \%$ recovery at an optimum $\mathrm{pH}$ of 7.5 and a temperature of $10^{\circ} \mathrm{C}$. Given the importance of psychrophilic actinobacteria $\mathrm{N}$. dassonvillei PSY13 can be further exploited for its benefits, meaning that the Southern Ocean harbours biotechnologically important microorganisms that can be further explored for versatile biotechnological and industrial applications.

\section{Introduction}

Antarctica in the South Pole is less studied compared to other habitats with reference to microbes. Temperatures in these cold environments ranged from $-1^{\circ} \mathrm{C}$ to $4^{\circ} \mathrm{C}$, which is expected to be severe [1]. In general, the extreme conditions lower the diversity of organisms. Hence, this environment remains less explored but can offer vast options to the researchers to study and explore the microbial diversity and ecological functions. Archer et al. [2] have explored the Antarctic environment to find out the presence of actinobacteria and to describe their distribution pattern. Most of the studies have reported on Antarctic ice, benthic region and glacier waters. However, studies on the community of bacterioplanktons in the Southern Ocean, particularly, actinobacteria are infrequent compared to the ice and soil reports [3]. Goodfellow and Haynes [4] have already described several specific isolation strategies to enumerate the actinobacterial population from different habitual environments. The Antarctic environment requires a significant emphasis on the elucidation of actinobacteria towards their distribution and ecological evaluation. The isolation media to be used need to have minimal nutrients with required vitamins and amino acids to promote the growth and multiplication of these organisms.

Interestingly, the microbes from the cold environment are provided with special mechanisms, which favour their survival at extreme conditions. These special mechanisms aid in the production of novel molecules such as cold-active enzymes having biotechnological applications as they possess higher catalytic activities. D'Amico et al. [5] have reported that the enzymes of the cold adapted organisms are highly active than their mesophilic counterparts. These enzymes show ten times higher activities than the enzymes obtained from the terrestrial microorganisms [6]. As a consequence of these features, microbes have been commonly used for many eco-biotechnology viewpoints [7]. Plants mostly consist of cellulosic carbohydrates and are recognized to be the earth's most reproducible source of energy. Cellulosic 
components are significantly involved in the global carbon cycle. Cold-active cellulases are responsible for more than $80 \%$ of the cellulose recycling in the cryosphere [8].

Medie et al. [9] explained the three types of cellulases such as endogluconase, exogluconase and glucosidase, which are are involved in the catalytic breakdown of the cellulose complex. Hayashi et al. [10] have reported the novel cold-active cellulase from Acremonium alcalophilum, which was active at 40 ${ }^{\circ} \mathrm{C}$. The enzymes derived from the cold environment had 20 to $40^{\circ} \mathrm{C}$ as the optimum temperatures for higher activities [11]. Cellulases are secreted by different types of micro-organisms. Psychrophiles are the right candidates for the production of enzymes that are active at low temperatures. Such psychrophilic enzymes are active in the presence of alkaline conditions and detergents and therefore have the characteristics to be used in the preparations of laundry additives. In addition, these enzymes can also be used for bioremediation of biomass derived from domestic and agricultural practices [12]. In particular, psychrophilic cellulases have been shown to have higher degradation efficiencies for lignocellulosic biomass and may have enormous potential in the bioenergy sector $[13,14]$. Nevertheless, cellulose is usually converted into bioethanol at relatively high temperatures $\left(50-60^{\circ} \mathrm{C}\right)$ and may, therefore, raise consumption and production costs [15]. Alternatively, cold-active cellulases can be used in the biofuel industry to reduce energy consumption as they have been proven to convert cellulose as ethanol at low temperatures. In addition, cold-active cells can also be used in various sectors, such as pulping in the paper industry, biopolishing in textiles and silage in food and feed formulations [12, 14]. Given the importance, the study was intended to identify the potential for cold-active cellulase of actinobacteria isolated from the Southern Ocean's Polar Front region.

\section{Materials And Methods \\ 2.1 Sample collection}

Water samples were obtained from the SOE-7 expedition (SOE-2012-13). The samples were obtained at the Polar Frontal region (PF1: Lat - 53.14; Long 47.82, PF2: Lat - 56.76; Long 57.72) of the Southern Ocean, using Conductivity/ Temperature/ Depth (CTD), a profile (SEABIRD 911 plus, USA) sampler. Seawater was filtered using a membrane filter $(0.22 \mu \mathrm{m})$, was stored in $20 \%$ glycerol suspension and used for the isolation of actinobacteria.

\subsection{Isolation and identification of actinobacteria}

A $100 \mu \mathrm{l}$ of the sample was spread on various media such as Starch Casein Nitrate Agar (SCNA), International Streptomyces Project-2 (ISP2), and Antarctic Minimal Medium (AMM), Actinomycete Isolation Agar (AIA) and Arginine-Vitamin Agar (AV), added with Mycostatin $(50 \mu \mathrm{g} / \mathrm{mL})$ and cycloheximide $(50 \mu \mathrm{g} / \mathrm{mL})$. Later, the plates were kept for incubation at $10^{\circ} \mathrm{C}$ and at $20^{\circ} \mathrm{C}$, for the recovery of psychrophilic and psychrotolerant actinobacteria in 60 days [16]. Morphologically distinct actinobacterial strains were subcultured on AV agar and subjected to further analyses. The morphological, physiological and chemotaxonomical characteristics were assessed for the identification of the selected actinobacterial strains $[17,18]$, the obtained results were verified using $[19]$ and justified at 
the genus level. In addition, the taxonomic position of the strains was studied by sequencing the $16 \mathrm{~S}$ rRNA gene. Genomic DNA was extracted [20] and amplified using the high $\mathrm{G}+\mathrm{C}$ gram-positive primers (27F-5'-AGAGTTTGATCCTGGCTCAG-3', 1492R-5'-TACGGCTACCTTGTTACGACTT-3'); the PCR conditions were followed as per the method [21]. The amplified product was purified using the Qiagen PCR purification kit, followed by sequencing (Applied Biosystems-3100, Macrogen Inc.-Republic of Korea). Two-way sequencing was done and assembled in an EZ-Taxon server and the closest neighbour details were obtained in BLAST. N-J (Neighbour-joining) algorithm was used to construct the phylogenetic tree to delineate the lineage of the actinobacteria. The 1000 replicate bootstrapping was used to evaluate the phylogenetic tree topology.

\subsection{Cardinal temperature determination}

The selected actinobacterial strains were tested for cardinal temperatures to justify the optimum temperature for growth so as to differentiate the psychrophiles from psychrotolerants. The strains isolated at 10 and $20^{\circ} \mathrm{C}$ were grown separately in AV liquid medium at various temperatures $(0,5,10,15$, 20 and $25^{\circ} \mathrm{C}$ for psychrophiles and $5,10,15,20,25$ and $30^{\circ} \mathrm{C}$ for psychrotolerants, respectively) for 25 days to ascertain their optimal temperature requirements. After incubation, aliquots were plated on AV agar medium and were incubated for 25 days at their respective temperatures to assess the viability of the actinobacteria [22]. The experiments were conducted as triplicates and the mean values were reported.

\subsection{Cold-active cellulase screening}

Fresh cultures of the actinobacterial strains were cross streaked on basal mineral salt medium (BSM) (composed of $\mathrm{CMC}$ sodium salt 2.0, $\mathrm{NaNO}_{3} 2.0, \mathrm{~K}_{2} \mathrm{HPO}_{4} 1.0, \mathrm{MgSO}_{4} 0.5, \mathrm{KCl} 0.5$, peptone 0.2 and agar 18 $(\mathrm{g} / \mathrm{L}))$ and kept at $10^{\circ} \mathrm{C}$ for 25 days. Then, the cellulolytic activities of the strains were detected by flooding with $1 \%$ iodine solution ( $1 \%$ iodine in $2 \% \mathrm{KOI}$ ) and were kept for 10 min under room temperature; then, de-stained with $1 \mathrm{MNaCl}$ to visualize the zones of clearance around the actinobacterial colonies. Strains found with potential cellulolytic activities were used for further enzyme production.

\subsection{Production and purification of cold-active cellulase enzyme}

Actinobacterial spores aseptically collected and suspended in sterile distilled water were used as inoculum for the cold-active cellulase enzyme production. $10 \mathrm{~mL}$ of the spore suspension $\left(5.6 \times 10^{7}\right.$ spores $/ \mathrm{mL}$ ) was inoculated in $500 \mathrm{~mL}$ of $\mathrm{BSM}$ containing $2 \% \mathrm{CMC}(\mathrm{pH} 7.0)$ for submerged fermentation and the flask was incubated at $10^{\circ} \mathrm{C}$ for 25 days by providing with intermittent shaking. After production, the flasks were spun in a centrifuge at $10,000 \mathrm{rpm}$ for $15 \mathrm{~min}$ at $4^{\circ} \mathrm{C}$. Cell free solutions were added with ammonium sulphate (saturated up to $70 \%$ ) and kept overnight at $4^{\circ} \mathrm{C}$ to precipitate the enzyme. The precipitate obtained by centrifugation $\left(9,000 \mathrm{rpm}\right.$ for $10 \mathrm{~min}$ at $\left.4^{\circ} \mathrm{C}\right)$ was suspended in $10 \mathrm{mM}$ Tris-HCl buffer ( $\mathrm{pH}$ 8.0) and kept overnight for dialysis. Then, the dialysate was loaded on a Sephadex column G$50(2.5 \times 50 \mathrm{~cm})$ preequilibrated with $50 \mathrm{mM}$ Tris-HCl buffer $(\mathrm{pH} \mathrm{7.5)}$ and the bound enzyme was eluted using the same buffer at $0.2 \mathrm{~mL} / \mathrm{min}$ flow rate. Fractions with cellulase activity were pooled and 
precipitated using ammonium sulphate and dialyzed with $10 \mathrm{mM}$ Tris- $\mathrm{HCl}$ buffer (pH 7.0). Then, the dialysate was loaded on a Fast Flow Q-Sepharose column $(1.6 \times 10 \mathrm{~cm}$, GE Healthcare), preequilibrated with $50 \mathrm{mM}$ Tris- $\mathrm{HCl}$ buffer $(\mathrm{pH}$ 9.0). Elution was done using linear gradient $\mathrm{NaCl}(0.1-0.5 \mathrm{M})$ at 0.3 $\mathrm{mL} / \mathrm{min}$ flow rate. Fractions showing higher cellulase activities were pooled and used for SDS-PAGE analysis.

\subsection{Enzyme assay and protein determination}

Dinitro salicylic acid (DNS) method was employed to test the cellulose hydrolytic activity of the coldactive cellulase on carboxymethyl cellulose (CMC) as a substrate and glucose was used as the standard [23]. Enzyme activity was estimated by observing the reducing sugars liberated from the CMC prepared in Tris- $\mathrm{HCl}$ buffer $(50 \mathrm{mM})$ at $\mathrm{pH}$ 8.0. The reaction was performed by incubating the solution at $25^{\circ} \mathrm{C}$ for 10 min and terminated by adding the DNS solution. The enzyme treated sample was boiled, cooled and the optical density was measured at $540 \mathrm{~nm}$. The protein concentration of the purified enzyme was determined according to the method of [24] by using a microplate reader. Bovine Serum Albumin (BSA) was used as the standard to generate the standard curve. The absorbance of the reaction mixture was read at $595 \mathrm{~nm}$. The test was carried out in triplicates and the mean values were calculated.

\subsubsection{Molecular weight determination using SDS-PAGE}

The purity and the molar mass of the enzyme were estimated using SDS-PAGE (12\% gel). The purified enzyme sample was added with Laemmli sample buffer and boiled for $5 \mathrm{~min}$ and then, loaded onto $12 \%$ gel. A 6.5-97.4 kDa protein ladder from Genaxy Scientific was used as the molecular weight marker. After electrophoresis, the gel was stained with Coomassie Brilliant Blue (CBB) R-250 (0.25\%) and the molecular weight was determined using the Total lab imaging software.

\subsection{Determination of optimal $\mathrm{pH}$ and temperature for activity and stability of the cold-active cellulase}

Determination of optimal $\mathrm{pH}$ and temperature for enzyme activity and stability was carried out as per the standard protocol, using $\mathrm{CMC}(1 \%)$ as the substrate. Different buffer systems were used for different $\mathrm{pH}$ values such as pH 3.0 to 6.0 (citrate buffer- $10 \mathrm{mM}$ ), pH 6.0 to 7.5 (sodium phosphate buffer- $10 \mathrm{mM}$ ), pH 7.5 to 9.0 (Tris- $\mathrm{HCl}-10 \mathrm{mM}$ ), and pH 9.0 to 11.0 (glycine- $\mathrm{NaOH}-10 \mathrm{mM}$ ). After incubation at $10^{\circ} \mathrm{C}$ for $60 \mathrm{~min}$, the reducing sugar products were estimated by the standard DNS method. The enzyme was incubated for $60 \mathrm{~min}$ at $10^{\circ} \mathrm{C}$ as stated above for assessing the stability of the enzyme at different $\mathrm{pH}$ levels. The effects of temperature on enzyme activity and stability were determined using $1 \% \mathrm{CMC}(10 \mathrm{mM}$ Tris $-\mathrm{HCl}$, $\mathrm{pH}$ 8.0) as the substrate. The purified enzyme was added to $\mathrm{CMC}$ and was incubated at different temperatures ranging from 0 to $80^{\circ} \mathrm{C}$ for $60 \mathrm{~min}$, and finally, DNS solution was added to stop the reaction and the residual activity was recorded as stated above. Upon determining the optimal temperature, the purified cellulase was incubated on a $\mathrm{CMC}$ agar plate at $10^{\circ} \mathrm{C}$ for one hour to justify the enzyme activity.

\subsection{Statistical analysis}


All experimental data were subjected to one-way Analysis of Variance (ANOVA). Dunnett's multiple comparison (GraphPad Prism v7.0) was also used to determine the difference among means at the level of 0.05 .

\section{Results And Discussion}

\subsection{Isolation and recovery of the actinobacteria from Polar Frontal waters}

Isolation showed a higher psychrophilic actinobacterial population density $\left(0.3 \times 10^{2} \mathrm{CFU} \mathrm{mL}^{-1}\right)$ in the PF1 sample followed by lower psychrophilic actinobacterial population density $\left(0.2 \times 10^{2} \mathrm{CFU} \mathrm{mL}^{-1}\right)$ in the PF2 sample in the AV agar medium. Whereas, the psychrotolerant actinobacterial forms were found to be same $\left(0.6 \times 10^{2} \mathrm{CFU} \mathrm{mL}{ }^{-1}\right)$ at the PF1 and PF2 samples in the AV agar medium. The other media were unable to capture actinobacteria when the AV medium was able to report higher population density (Fig. 1A). In the AV medium, the microbial population density was increased because trace vitamins and nutrients were supplied through minimal media. In addition, the AV medium consisted of essential vitamins and glycerol that could have had a significant impact on actinobacterial growth. In addition, media-containing starch (SCNA and AMM) was also found to support actinobacterial growth. The other AIA media consisted of a source of nitrogen (sodium caseinate or asparagine) that might have stimulated the growth of actinobacteria. Pearce et al. [25] research have suggested that the supplementation of nutrients in the isolation media would help to increase the bacterial population. ISP2 showed no growth among the five isolation media used, yet it was reported to improve actinobacteria growth in other aquatic and terrestrial counterparts [26].

\subsection{Identification of actinobacterial strains}

Actinobacterial strains have been identified by conventional and molecular methods. Morphological analysis showed that the cold loving strains had white, olive green and white yellow aerial mycelia. The cold tolerant strains produced white and gray aerial mycelia. Micromorphological observations showed spiral, rectiflexible, long and branched, spiral and rectiflexible spore chains in the actinobacterial strains. Chemo-taxonomical analysis of actinobacterial strains has shown that meso-DAP is found to be present in the PSY13, PSY15 and PSY21 strains of the nine actinobacterial strains. However, their cell walls did not have any detectable sugars. The cell walls of these strains were therefore known as a type III cell wall. In addition, the strains' spore chains are elongated, segmented and long. In summarizing these results, the strains were found to be the closest to the Nocardiopsis genus and thus confirmed as Nocardiopsis candidate species. LL-DAP and glycine are found in the cell walls of the remaining six strains.

Nevertheless, their cell walls had no signature sugars, so they were listed as a type I cell wall. The six strains were shown to be Streptomyces' closest neighbor with all these findings and were assumed to belong to the Streptomyces genus. Additionally, the strain colonies were mostly powdery and elongated, and the strains displayed the typical morphological characteristics of the actinobacteria. Therefore, the 
actinobacteria's main characteristics are focused on their spore morphology and the form of spore chain which varies from species to species. Apart from these characteristics, the use of the carbon source is also considered to be a key distinguishing feature of the actinobacteria genus. The PSY and PST 16S genes have been sequenced and deposited in the NCBI GenBank repository (Accession Nos: KY120275, KY120276, KY120277, KY120278, KY120279, KY120280, KY120281, KY120282, KY120283, KY120279). The phylogenetic association of the nine strains is shown in Table 1. All nine strains are phylogenetically classified into actinobacteria and phylogenetic neighbors of PSY13, PSY15, PSY21, PSY25, PST1, PST2, PST3, PST4 and PST5 were found to be Nocardiopsis dassonvillei, N. prasina, N. alba, S. albus, S. albidoflavus, S. exfoliates, S. pactum, S. griseorubens and S. althioticus, respectively (Fig. 2) (Supplementary file 1).

Table 1

Phylogenetic placements of the psychrophilic and psychrotolerant actinobacteria of the Polar Frontal waters of the Antarctica.

\begin{tabular}{|c|c|c|c|c|c|}
\hline $\begin{array}{l}\text { Strain } \\
\text { No. }\end{array}$ & $\begin{array}{l}\text { Accession } \\
\text { No. }\end{array}$ & $\begin{array}{l}\text { Sequence Length } \\
\text { (bp) }\end{array}$ & $\begin{array}{l}\text { Closest Phylogenetic } \\
\text { Neighbor }\end{array}$ & $\begin{array}{l}\text { Accession } \\
\text { No. }\end{array}$ & $\begin{array}{l}\text { Identity } \\
\text { (\%) }\end{array}$ \\
\hline \multicolumn{6}{|c|}{ Psychrophilic actinobacteria } \\
\hline PSY13 & KY120275 & 1466 & Nocardiopsis dassonvillei & NR 029314 & 99.7 \\
\hline PSY15 & KY120276 & 1443 & Nocardiopsis prasina & NR 044906 & 99.6 \\
\hline PSY21 & KY120277 & 1437 & Nocardiopsis alba & NR 026340 & 98.6 \\
\hline PSY25 & KY120278 & 1483 & Streptomyces albus & NR 112341 & 99.9 \\
\hline \multicolumn{6}{|c|}{ Psychrotolerant actinobacteria } \\
\hline PST1 & KY120279 & 1376 & $\begin{array}{l}\text { Streptomyces } \\
\text { albidoflavus }\end{array}$ & NR 116634 & 100 \\
\hline PST2 & KY120280 & 1451 & Streptomyces exfoliatus & NR 041229 & 99.9 \\
\hline PST3 & KY120281 & 1470 & Streptomyces pactum & NR 041134 & 99.9 \\
\hline PST4 & KY120282 & 1466 & $\begin{array}{l}\text { Streptomyces } \\
\text { griseorubens }\end{array}$ & NR 041066 & 99.9 \\
\hline PST5 & KY120283 & 1450 & Streptomyces althioticus & NR 115392 & 99.9 \\
\hline PST1 & KY120279 & 1376 & $\begin{array}{l}\text { Streptomyces } \\
\text { albidoflavus }\end{array}$ & NR 116634 & 100 \\
\hline
\end{tabular}

Molecular analysis confirmed that actinobacterial strains have stronger correlations with Streptomyces and Nocardiopsis sp. Previous reports suggested that Streptomyces was disproportionately present in the waters of the Southern Ocean waters. Streptomyces was also found to be dominant in the Southern Ocean waters, as in the other environmental counterparts [27]. Studies of Lavin et al. [28] have also reported the presence of Streptomyces in the Fildes Peninsula soils of King George Island, Antarctica. Streptomyces are normally present in the oceanic habitats [29] and are found to be the important member 
among the actinobacteria, which are prevalent in the cryo environment with $80 \%$ recoverability [30]. Streptomyces fildesensis sp. nov. and Streptomyces hypolithicus sp. nov. have been recovered successfully from Antarctica and have been described as new species [31, 32].

Streptomyces are shown to have higher bioactivity as they dominate the environment despite increasing salinity and lowering temperatures under extreme conditions [33]. The present study recorded around $67 \%$ of the contribution of Streptomyces to help discover novel candidate organisms from intense marine habitats for their bioactive ability. Nocardiopsis has also been documented in this study in addition to Streptomyces, which are of immense interest for their bioactive potential and ecological functions. It is noticed that the genus Nocardiopsis is omnipresent, irrespective of the climate. N. dassonvillei, N. prasina and $N$. alba have been reported in the present study. $N$. dassonvillei was previously known as $N$. antarctica and was later reclassified as $N$. dassonvillei with the aid of advanced molecular techniques.

\subsection{Effect of temperature on the growth of psychrophilic and psychrotolerant actinobacteria}

The strains PSY13, PSY15, PSY21 and PSY25 were observed to grow well at an optimum temperature of $10^{\circ} \mathrm{C}$ and are therefore classified as psychrophiles (Fig. 1B). The strains PST1, PST2, PST3, PST4 and PST5 were observed to grow well at an optimum temperature of $20^{\circ} \mathrm{C}$ and are therefore classified as psychrotolerants. This temperature reliant classification would significantly help discriminate the organisms and design experiments to explore their bioactive potentials. Cavicchioli, [34] has reported the cardinal temperature of the cold loving organisms (psychrophiles) with $5^{\circ} \mathrm{C}$ as the minimum and $20^{\circ} \mathrm{C}$ as the maximum and $10^{\circ} \mathrm{C}$ as the optimum. However, the cardinal temperatures of the cold tolerant organisms (psychrotolerants) were determined with $10^{\circ} \mathrm{C}$ as the minimum and $25^{\circ} \mathrm{C}$ as the maximum and $20^{\circ} \mathrm{C}$ as the optimum.

\subsection{Cellulolytic activity}

In the cellulolytic screening test, the psychrophilic strain PSY13 was found to possess a higher cellulolytic activity than the other strains (Fig. 1D). The cellulose hydrolytic zone measured around $10 \mathrm{~cm}$ (Fig. 1E) and thus, justifying the cold-active cellulase potential of the psychrophilic actinobacterial strain in less than an hour. The cold-active cellulase production was justified by the supporting data reported by Buchon et al. [35], who have also proposed that temperature was highly influencing the cold adapted microorganisms for the production of cold-active enzymes. As these enzymes have a high biotechnological value, the focus on amylases, esterases, agarases and proteases are increasing and thus, will pave a way to utilize these novel enzymes in various industrial applications [36]. Particularly, cellulases posing cold-active capabilities and obtained from the microbes of Antarctic environments have vast industrial applications viz. food, brewery, feed, paper pulp and so on. In addition, the cellulases are having high values as they are abundantly utilized in the production of biofuels in the refining industry [37]. 


\subsection{Purification and molecular weight determination of cold-active cellulase}

The cold-active enzyme was recovered from the $N$. dassonvillei PSY13 culture supernatant and was purified as per the steps given in Table 2. The enzyme from the culture supernatant was processed through ammonium sulphate recovery and gel filtration chromatography using Sephadex G-50 followed by ion exchange chromatography (Q-Sepharose Fast Flow column). The active fraction (0.4M) was collected from the Q-Sepharose FF fractionation (Fig. 3A) and was concentrated; 5\% recovery was achieved with 22.9 -fold purification with a specific activity of $6.36 \mathrm{U} / \mathrm{mg}$. The cellulase purification fold can vary depending on the methods and matrix used for purification. Islam and Roy [38] has purified the cellulase from Bacillus sp. and reported that it has 9.7-fold purification in the CM-cellulose fractionation, which is comparatively low than the present study. Another study has reported 39.1-fold purification attained by the Sephadex G-75 column purification for the cellulase produced by $B$. vallismortis [39], which is relatively higher than the present study. Pachauri et al. [40] has also worked on fungal cellulase and reported that he has obtained 14.82 -fold purification with $25.8 \%$ yield. As mentioned in the previous statement, the purification fold and the specific activity of the enzymes depends greatly on the matrix / resin used in the purification process and thus helps to unfold the novel enzyme activity [41]. The enzyme was further spotted on $\mathrm{CMC}$ agar plate and incubated at $10^{\circ} \mathrm{C}$ and a strong cellulolytic activity was witnessed (Fig. 1E). The purified cold-active cellulase enzyme was observed with a mass of $48 \mathrm{kDa}$ as a distinct band in the SDS-PAGE analysis (Fig. 3B). The mass of the cellulase enzyme was higher than the others $(29.7 \mathrm{kDa}$ and $36.6 \mathrm{kDa}$ ) and in most of the cases, the cellulase will be having the mass ranging between 20 and $60 \mathrm{kDa}$ [42].

Table 2

Summary of the purification of the cold-active cellulase enzyme produced by $N$. dassonvillei PSY13.

\begin{tabular}{|llllllll|}
\hline $\begin{array}{l}\text { Purification } \\
\text { step }\end{array}$ & $\begin{array}{l}\text { Volume } \\
(\mathrm{ml})\end{array}$ & $\begin{array}{l}\text { Protein } \\
(\mathrm{mg} / \mathrm{mL})\end{array}$ & $\begin{array}{l}\text { Activity } \\
(\mathrm{U} / \mathrm{mL})\end{array}$ & $\begin{array}{l}\text { Total } \\
\text { activity } \\
(\mathrm{U})\end{array}$ & $\begin{array}{l}\text { Total } \\
\text { protein } \\
(\mathrm{mg})\end{array}$ & $\begin{array}{l}\text { Specific } \\
\text { activity } \\
(\mathrm{U} / \mathrm{mg})\end{array}$ & $\begin{array}{l}\text { Yield } \\
(\%)\end{array}$ \\
\hline $\begin{array}{l}\left(\mathrm{NH}_{4}\right)_{2} \mathrm{SO}_{4} \\
(70 \%)\end{array}$ & 15 & 3.2 & 6.791 & 101.865 & 48 & 2.12 & 15 \\
$\begin{array}{l}\text { Sephadex } \\
\text { G-50 }\end{array}$ & 11 & 1.7 & 4.76 & 52.36 & 18.7 & 2.80 & 11 \\
\hline $\begin{array}{l}\text { Q- } \\
\text { Sepharose } \\
\text { FF }\end{array}$ & 5 & 0.09 & 0.572 & 2.86 & 0.45 & 6.36 & 5 \\
\hline
\end{tabular}

\subsection{Optimal pH and temperature ranges for better stability and activity of the enzyme}

Optimal pH for cellulase activity was studied and a higher activity (>90\%) was recorded at $\mathrm{pH} 7.5$ followed by $\mathrm{pH} 8.0$ (80\%) and pH 9.0 (70\%), respectively. The enzyme was stable and active between $\mathrm{pH}$ 
6.5 to $\mathrm{pH} 9.0$ (Fig. 4A). Beyond this range, the enzyme was not stable and the activity was reduced. This was in agreement with the previous report, which showed a relatively higher activity at $\mathrm{pH} 7.5$ [43]. More recently, Shajahan et al. [44] have reported the cellulase produced by B. licheniformis. NCIM 5556 was stable and active between $\mathrm{pH} 4.5$ to 9.5 , and the enzyme was highly active at $\mathrm{pH} 6.5$. However, cellulase produced by the psychrotolerant yeast had a different optimal pH of 6.4 and thus, reported to be highly stable and active in that range [45].

The purified cellulase enzyme was found to be stable between $0{ }^{\circ} \mathrm{C}$ to $30^{\circ} \mathrm{C}$ and the optimal working temperature was recorded as $10^{\circ} \mathrm{C}$ with nearly $80 \%$ of the relative activity (Fig. 4B). However, the relative activity of the cold-active cellulase enzyme was maintained $>70 \%$ between the range of 10 to $40^{\circ} \mathrm{C}$. Beyond $40^{\circ} \mathrm{C}$, the enzyme's relative activity reduced gradually due to the instability of the enzyme in the hightemperature range. The higher catalytic nature of the cold-active enzymes $\left(<25^{\circ} \mathrm{C}\right)$ makes them novel biological catalysts. $\mathrm{Li}$ et al. [46] have reported the maximum activity of cellulase obtained at 10.4 ${ }^{\circ} \mathrm{C}$ and in the present study, cold-active cellulase exhibited a strong cellulolytic activity at $10^{\circ} \mathrm{C}$. In general, most of the cold-active enzymes have been reported to have the temperature optimum of 20 to $40{ }^{\circ} \mathrm{C}$. However, enzymes having higher catalytic activities $(80 \%)$ at $10{ }^{\circ} \mathrm{C}$ are considered novel [47]. Such lowtemperature dependency of enzymes makes them useful in various beverage and food industries where the process is performed under low temperatures. Therefore, the cold-active enzymes are holding more than $80 \%$ of the market share.

\section{Conclusion}

Actinobacterial strains were isolated from the Southern Ocean's Polar Frontal Waters. Nocardiopsis and Streptomyces were identified, among all the strains studied, the psychrophilic strain $N$. dassonvillei PSY13 showed a higher hydrolysing activity and their cold-active cellulase found to have specific activity of $6.36 \mathrm{U} / \mathrm{mg}$ and a molar mass of $48 \mathrm{kDa}$ with 7.5 and $10^{\circ} \mathrm{C}$ as the optimum pH and temperature respectively.

\section{Declarations}

\section{Acknowledgements}

The Science and Engineering Research Board - Department of Science and Technology (DST-SERB), National Postdoctoral Fellowship Scheme (N-PDF) (Grant number PDF/2016/003905) and the Department of Biotechnology (DBT) (Grant number BT/PR5426/AAQ/3/599/2012), Government of India, have supported the work. The authors thank for funding's by the Researchers Supporting Project Number (RSP-2021/293) King Saud University, Riyadh, Saudi Arabia.

\section{References}

1. Deming JW (2002) Psychrophiles and polar regions. Curr Opin Microbiol 5(3):301-309 
2. Archer SD, McDonald IR, Herbold CW, Lee CK, Cary CS (2015) Benthic microbial communities of coastal terrestrial and ice shelf Antarctic meltwater ponds. Frontiers in microbiology 6:485

3. Murray AE, Grzymski JJ (2007) Diversity and genomics of Antarctic marine micro-organisms. Philosophical Transactions of the Royal Society B: Biological Sciences 362(1488):2259-2271

4. Goodfellow M, Haynes J, Actinomycetes in marine sediments, Biological, biochemical and biomedical aspects of actinomycetes (1984) 453-472

5. D'Amico S, Marx J-C, Gerday C, Feller G (2003) Activity-stability relationships in extremophilic enzymes. J Biol Chem 278(10):7891-7896

6. Margesin R, Miteva V (2011) Diversity and ecology of psychrophilic microorganisms. Research in microbiology 162(3):346-361

7. Kasana RC (2010) Proteases from psychrotrophs: an overview. Crit Rev Microbiol 36(2):134-145

8. Grant S, Sorokin DY, Grant WD, Jones BE, Heaphy S (2004) A phylogenetic analysis of Wadi el Natrun soda lake cellulase enrichment cultures and identification of cellulase genes from these cultures. Extremophiles 8(5):421-429

9. Medie FM, Vincentelli R, Drancourt M, Henrissat B (2011) Mycobacterium tuberculosis Rv1090 and Rv1987 encode functional $\beta$-glucan-targeting proteins. Protein Exp Purif 75(2):172-176

10. Hayashi K, Nimura Y, Ohara N, Uchimura T, Suzuki H, Komacata K, Kozaki M (1996) Low-temperatureactive cellulase produced by Acremonium alcalophilum-JCM 7366-Note, Seibutsu-Kogaku KaishiJournal of the Society for. Fermentation Bioengineering 74(1):7-10

11. Zeng R, Xiong P, Wen J (2006) Characterization and gene cloning of a cold-active cellulase from a deep-sea psychrotrophic bacterium Pseudoalteromonas sp. DY3. Extremophiles 10(1):79-82

12. Kasana RC, Gulati A (2011) Cellulases from psychrophilic microorganisms: a review. J Basic Microbiol 51(6):572-579

13. Cavicchioli R, Charlton T, Ertan H, Omar SM, Siddiqui K, Williams T (2011) Biotechnological uses of enzymes from psychrophiles. Microbial biotechnology 4(4):449-460

14. Bai X, Yuan X, Wen A, Li J, Bai Y, Shao T (2016) Cloning, expression and characterization of a coldadapted endo-1, 4- $\beta$-glucanase from Citrobacter farmeri A1, a symbiotic bacterium of Reticulitermes labralis. PeerJ 4:e2679

15. Tiwari R, Nain PK, Singh S, Adak A, Saritha M, Rana S, Sharma A, Nain L (2015) Cold active holocellulase cocktail from Aspergillus niger SH3: process optimization for production and biomass hydrolysis. Journal of The Taiwan institute of Chemical Engineers 56:57-66

16. Lo Giudice A, Brilli M, Bruni V, De Domenico M, Fani R, Michaud L (2007) Bacterium-bacterium inhibitory interactions among psychrotrophic bacteria isolated from Antarctic seawater (Terra Nova Bay, Ross Sea. FEMS Microbiol Ecol 60(3):383-396

17. Shirling ET, Gottlieb D (1966) Methods for characterization of Streptomyces species. Int J Syst Bacteriol 16(3):313-340 
18. Lechevalier MP, Lechevalier H (1970) Chemical composition as a criterion in the classification of aerobic actinomycetes. Int J Syst Evol Microbiol 20(4):435-443

19. Nonomura H (1974) Key for classification and identification of 458 species of the streptomycetes included in ISP. J Ferment Technol 52:78-92

20. Everest GJ, Roes-Hill M, Omorogie C, Cheung S-K, Cook AE, Goodwin CM, Meyers PR (2013) Amycolatopsis umgeniensis sp. nov., isolated from soil from the banks of the Umgeni River in South Africa. Antonie Van Leeuwenhoek 103(3):673-681

21. ZHAO SX, YE FY (2011) Enhancement of PCR amplification of actinobacterial 16S rRNA gene using an adjuvant, dimethyl sulphoxide. Curr Sci 101(1):22

22. Helmke E, Weyland $H$ (2004) Psychrophilic versus psychrotolerant bacteria-occurrence and significance in polar and temperate marine habitats. Cellular molecular biology 50(5):553-561

23. Miller GL, Blum R, Glennon WE, Burton AL (1960) Measurement of carboxymethylcellulase activity. Anal Biochem 1(2):127-132

24. Bradford MM (1976) A rapid and sensitive method for the quantitation of microgram quantities of protein utilizing the principle of protein-dye binding. Anal Biochem 72(1-2):248-254

25. Pearce DA, Van Der Gast CJ, Woodward K, Newsham KK (2005) Significant changes in the bacterioplankton community structure of a maritime Antarctic freshwater lake following nutrient enrichment. Microbiology 151(10):3237-3248

26. Lee L, Zainal N, Azman A, Eng S, Goh B, Yin W, Ab Mutalib N, Chan K, Diversity and antimicrobial activities of actinobacteria isolated from tropical mangrove sediments in Malaysia. Sci. World J. 2014, 2014

27. Kamala K, Sivaperumal P, Gobalakrishnan R, Swarnakumar N, Rajaram R (2015) Isolation and characterization of biologically active alkaloids from marine actinobacteria Nocardiopsis sp. Biocatal Agric Biotechnol NCS1(1):63-69 4 ))

28. Lavin PL, Yong ST, Wong CM, De Stefano M (2016) Isolation and characterization of Antarctic psychrotroph Streptomyces sp. strain INACH3013. Antarct Sci 28(6):433-442

29. Ramesh S, Jayaprakashvel M, Mathivanan N (2006) Microbial status in seawater and coastal sediments during pre-and post-tsunami periods in the Bay of Bengal, India. Mar Ecol 27(3):198-203

30. Babalola OO, Kirby BM, Roes-Hill ML, Cook AE, Cary SC, Burton SG, Cowan DA (2009) Phylogenetic analysis of actinobacterial populations associated with Antarctic Dry Valley mineral soils. Environ Microbiol 11(3):566-576

31. Le Roes-Hill M, Rohland J, Meyers PR, Cowan DA, Burton SG (2009) Streptomyces hypolithicus sp. nov., isolated from an Antarctic hypolith community. Int J Syst Evol MicroBiol 59(8):2032-2035

32. Li J, Tian X-P, Zhu T-J, Yang L-L, Li W-J (2011) Streptomyces fildesensis sp. nov., a novel streptomycete isolated from Antarctic soil. Antonie Van Leeuwenhoek 100(4):537

33. Encheva-Malinova $M$, Stoyanova $M$, Avramova $H$, Pavlova $Y$, Gocheva $B$, Ivanova I, Moncheva $P$ (2014) Antibacterial potential of streptomycete strains from Antarctic soils. Biotechnology 
Biotechnological Equipment 28(4):721-727

34. Cavicchioli R (2016) On the concept of a psychrophile. ISME J 10(4):793

35. Buchon L, Laurent P, Gounot A, Guespin-Michel J (2000) Temperature dependence of extracellular enzymes production by psychrotrophic and psychrophilic bacteria. Biotech Lett 22(19):1577-1581

36. Tomova I, Gladka G, Tashyrev A, Vasileva-Tonkova E (2014) Isolation, identification and hydrolytic enzymes production of aerobic heterotrophic bacteria from two Antarctic islands. International Journal of Environmental Sciences 4(5):614

37. Juturu V, Wu JC (2014) Microbial cellulases: engineering, production and applications. Renew Sustain Energy Rev 33:188-203

38. Islam F, Roy N (2018) Screening, purification and characterization of cellulase from cellulase producing bacteria in molasses. BMC Res Notes 11(1):445

39. Gaur R, Tiwari S (2015) Isolation, production, purification and characterization of an organic-solventthermostable alkalophilic cellulase from Bacillus vallismortis RG-07. BMC Biotechnol 15(1):19

40. Pachauri P, More S, Sullia S, Deshmukh S (2020) Purification and characterization of cellulase from a novel isolate of Trichoderma longibrachiatum. Biofuels 11(1):85-91

41. Kumar B, Bhardwaj N, Alam A, Agrawal K, Prasad H, Verma P (2018) Production, purification and characterization of an acid/alkali and thermo tolerant cellulase from Schizophyllum commune NAIMCC-F-03379 and its application in hydrolysis of lignocellulosic wastes. AMB Express 8(1):173

42. Bai H, Zi H, Huang Y, Han M, Irfan M, Liu N, Yang J, Wang H, Han X (2017) Catalytic Properties of Carboxymethyl Cellulase Produced from Newly Isolated Novel Fungus Penicillium ochrochloron ZH1 in Submerged Fermentation. Catal Lett 147(8):2013-2022

43. Kim B-K, Lee B-H, Lee Y-J, Jin I-H, Chung C-H, Lee J-W (2009) Purification and characterization of carboxymethylcellulase isolated from a marine bacterium, Bacillus subtilis subsp. subtilis A-53. Enzyme Microbial Technology 44(6-7):411-416

44. Shajahan S, Moorthy IG, Sivakumar N, Selvakumar G (2017) Statistical modeling and optimization of cellulase production by Bacillus licheniformis NCIM 5556 isolated from the hot spring, Maharashtra, India. Journal of King Saud University-Science 29(3):302-310

45. Carrasco M, Villarreal P, Barahona S, Alcaíno J, Cifuentes V, Baeza M (2016) Screening and characterization of amylase and cellulase activities in psychrotolerant yeasts. BMC microbiology 16(1):21

46. Li D, Feng L, Liu K, Cheng Y, Hou N, Li C (2016) Optimization of cold-active CMCase production by psychrotrophic Sphingomonas sp. FLX-7 from the cold region of China. Cellulose 23(2):1335-1347

47. Santiago M, Ramírez-Sarmiento CA, Zamora RA, Parra LP (2016) Discovery, molecular mechanisms, and industrial applications of cold-active enzymes. Frontiers in microbiology 7:1408

\section{Figures}



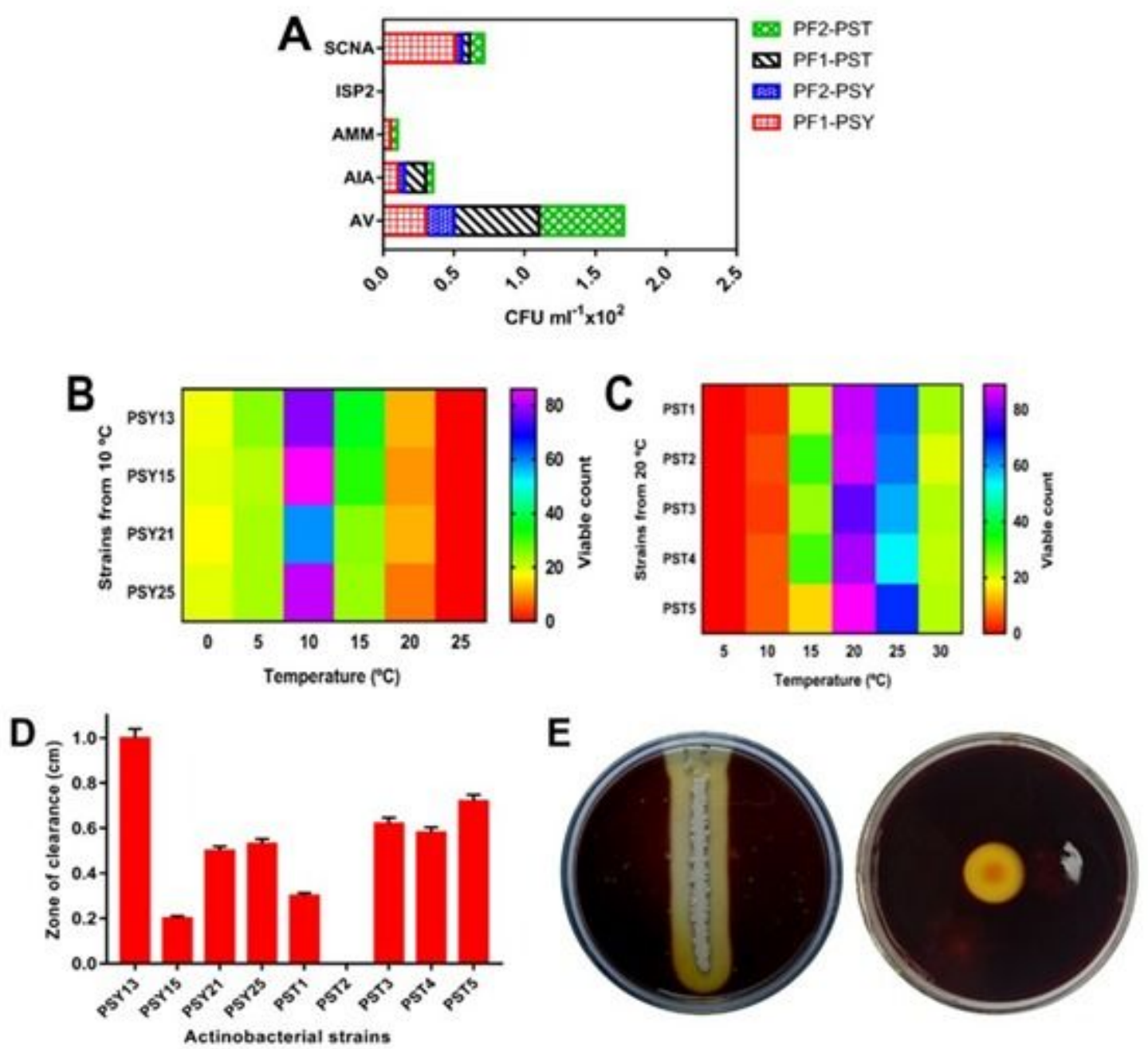

\section{Figure 1}

A) Population density of psychrophilic and psychrotolerant actinobacteria obtained at the PF1 and PF2, in different isolation media (SCNA, ISP2, AMM, AIA and AV), Viable count of the psychrophilic (B) and psychrotolerant (C) actinobacteria at various temperature ranges, D) Extracellular cellulolytic activity of the psychrophilic and psychrotolerant actinobacteria, E) Proven cellulolytic activity of the psychrophilic actinobacterium N. dassonvillei PSY13 and strong cellulolytic activity demonstrated by the purified coldactive cellulase enzyme from $\mathrm{N}$. dassonvillei PSY 13 at $10^{\circ} \mathrm{C}$ in $1 \mathrm{~h}$. 


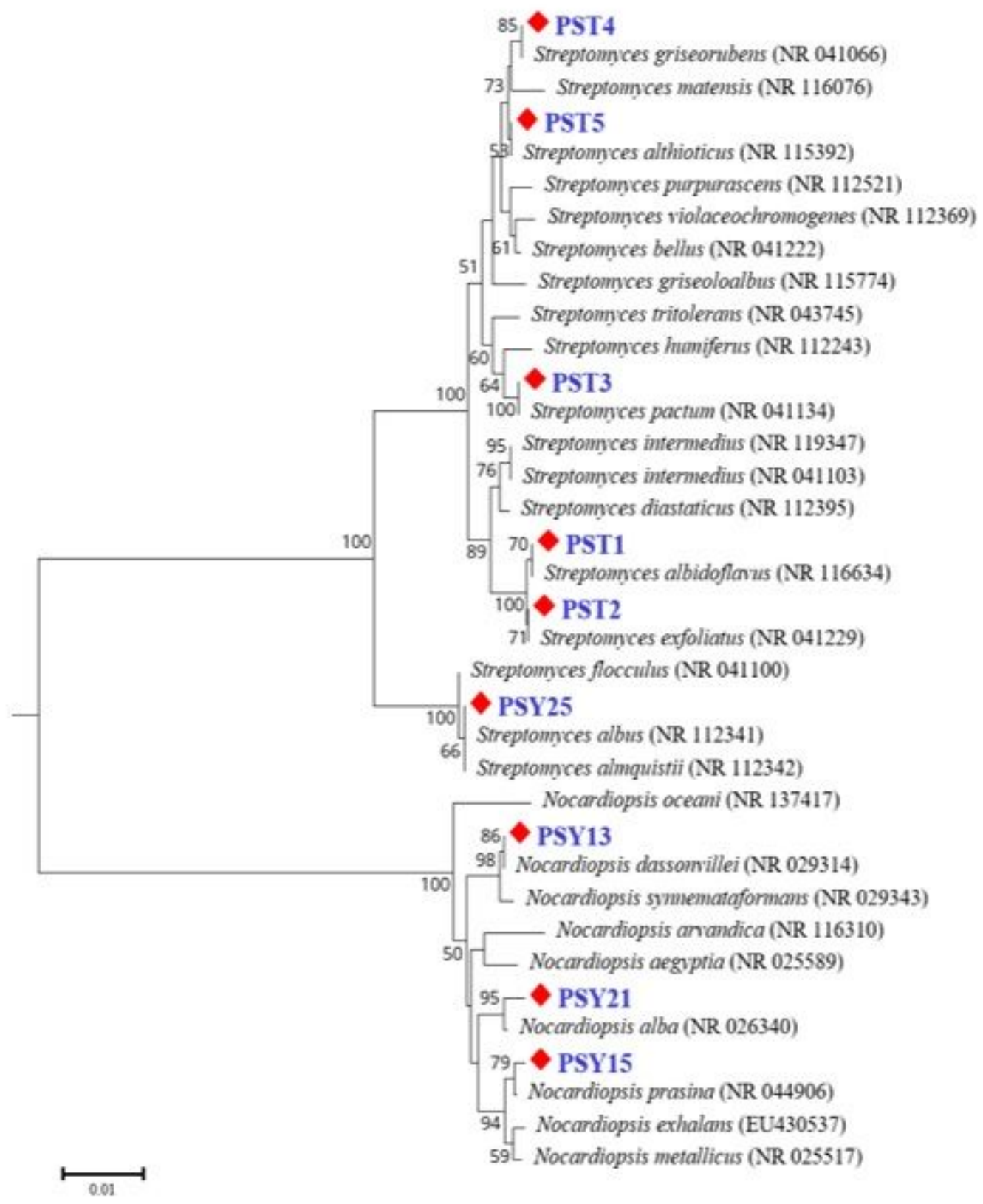

Figure 2

Neighbour-joining tree showing the phylogenetic placement of actinobacterial strains with their closest neighbours, determined by sequencing $16 \mathrm{~S}$ ribosomal gene. 

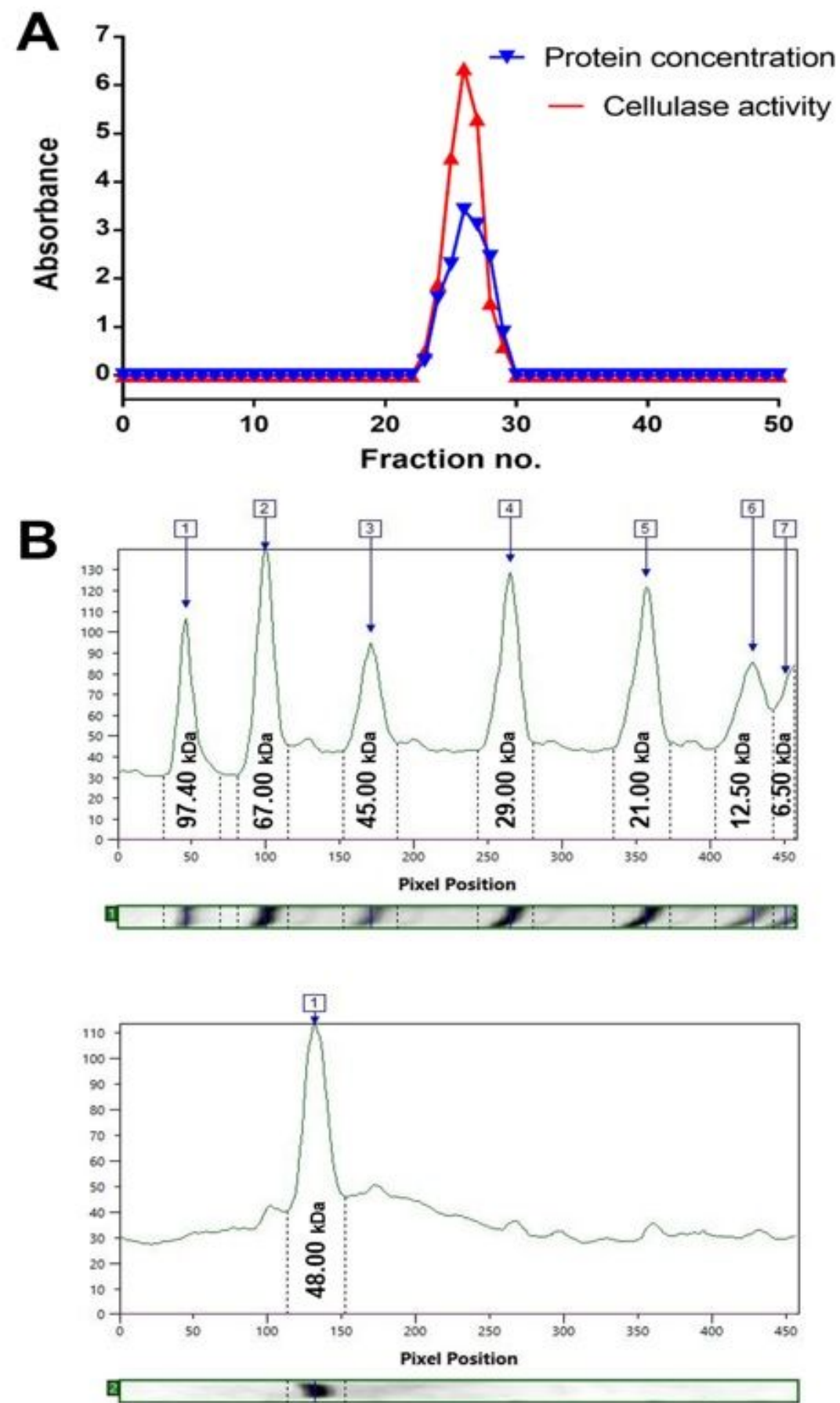

\section{Figure 3}

Q-Sepharose FF elution profile (A) and Totallab molecular weight analysis of SDS-PAGE (B) of the coldactive cellulase enzyme produced by N. dassonvillei PSY13. 
A
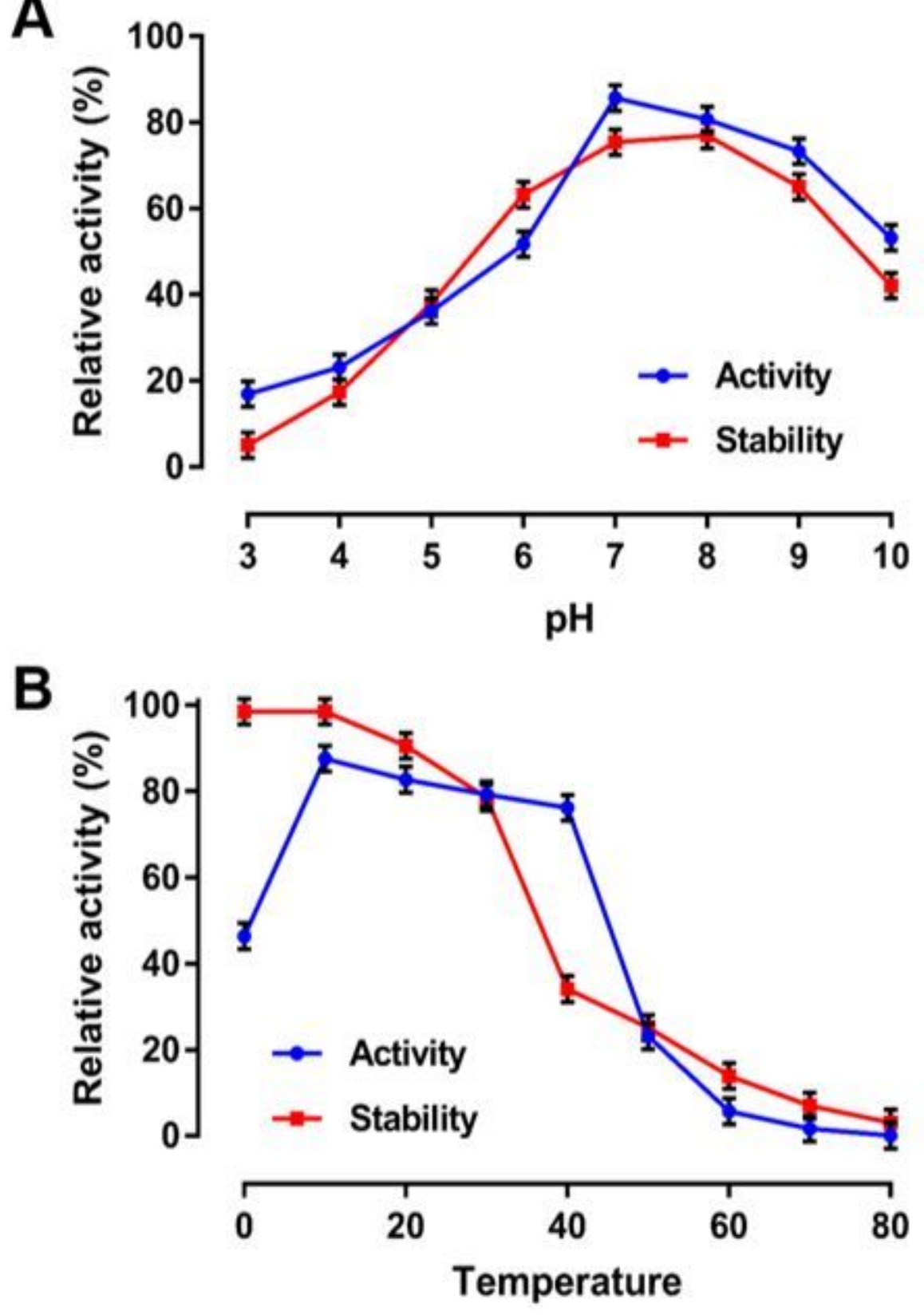

Figure 4

Effect of $\mathrm{pH}(\mathrm{A})$ and temperature (B) on the relative activity of the cold-active cellulase produced by $\mathrm{N}$. dassonvillei PSY13. 